\title{
Pathway of phytate dephosphorylation by $\beta$-propeller phytases of different origins
}

\author{
Ralf Greiner, Boon L. Lim, Chiwai Cheng, and Nils-Gunnar Carlsson
}

\begin{abstract}
Using a combination of high-performance ion chromatography analysis and kinetic studies, the pathway of myoinositol hexakisphosphate dephosphorylation by the $\beta$-propeller phytase of Shewanella oneidensis was established, which was then compared with that of Bacillus subtilis 168, Bacillus amyloliquefaciens ATCC 15841, and B. amyloliquefaciens $45 \beta$-propeller phytases. The data demonstrate that all of these $\beta$-propeller phytases dephosphorylate myo-inositol hexakisphosphate in a stereospecific way by sequential removal of phosphate groups via $\mathrm{D}-\operatorname{Ins}(1,2,4,5,6) \mathrm{P}_{5}, \operatorname{Ins}(2,4,5,6) \mathrm{P}_{4}$ to finally $\operatorname{Ins}(2,4,6) \mathrm{P}_{3}$. Thus, the $\beta$-propeller phytases prefer the hydrolysis of every second phosphate over that of adjacent ones. This finding does not support previous phytate degradation models proposed by J. Kerovuo, J. Rouvinen, and F. Hatzack (2000. Biochem. J. 352: 623-628) and R. Greiner, A. Farouk, M. Larsson Alminger, and N.G. Carlsson (2002. Can. J. Microbiol. 48: 986-994), but seems to fit with the structural model given by S. Shin, N.C. Ha, B.C. Oh, T.K. Oh, and B.H. Oh (2001. Structure, 9: 851-858).
\end{abstract}

Key words: Bacillus spp., $\beta$-propeller phytase, myo-inositol phosphate isomers, phytate degradation, Shewanella oneidensis.

Résumé : La voie de déphosphorylation du myo-inositol hexakisphosphate par la phytase $\beta$-hélicoïdale de Shewanella oneidensis a été établie grâce à l'utilisation combinée de chromatographie liquide à haute performance et d'analyses cinétiques, et a été comparée aux phytases $\beta$-hélicoïdales de Bacillus subtilis 168, Bacillus amyloliquefaciens ATCC 15841 et de $B$. amyloliquefaciens 45 . Les résultats démontrent que toutes ces phytases $\beta$-hélicoïdales déphosphorylent le myo-inositol hexakisphosphate de façon stéréospécifique en enlevant les groupes phosphates produisant le D-Ins $(1,2,4,5,6) \mathrm{P}_{5}$, le $\operatorname{Ins}(2,4,5,6) \mathrm{P}_{4}$ pour finalement générer le Ins $(2,4,6) \mathrm{P}_{3}$. Ainsi, les phytases $\beta$-hélicoïdales préfèrent hydrolyser à tous les deux phosphates comparativement aux phosphates adjacents. Ces résultats n'appuient pas les précédents modèles de dégradation du phytate proposés par J. Kerovuo, J. Rouvinen et F. Hatzack (2000. Biochem. J. 352: 623-628) et R. Greiner, A. Farouk, M. Larsson Alminger et N.G. Carlsson (2002. Can. J. Microbiol. 48: 986-994), mais semblent concorder avec le modèle structural proposé par S. Shin, N.C. Ha, B.C. Oh, T.K. Oh et B.H. Oh (2001. Structure, 9: 851-858).

Mots-clés : Bacillus spp., phytase $\beta$-hélicoïdale, isomères du myo-inositol phosphate, dégradation du phytate, Shewanella oneidensis.

[Traduit par la Rédaction]

\section{Introduction}

Phytases play a crucial role in the recycling of phytatephosphorus in the biosphere. Based on their amino acid sequence identity and catalytic mechanisms, phytases can be grouped into four classes: histidine acid phosphatase (HAP), purple acid phosphatase (PAP), $\beta$-propeller phytase (BPP), and cysteine phytase (CP) (Mullaney and Ullah 2005). Among these phytases, the BPP family is the only class that exhibits phytase activity at neutral and alkaline pH. Phytases that are constituted by a single BPP domain

Received 14 September 2006. Revision received 7 December 2006. Accepted 7 December 2006. Published on the NRC

Research Press Web site at cjm.nrc.ca on 23 May 2007.

R. Greiner. ${ }^{1}$ Centre for Molecular Biology, Federal Research Centre for Nutrition and Food, Haid-und-Neu-Strasse 9,

D-76131 Karlsruhe, Germany.

B.L. Lim and C. Cheng. Department of Zoology, University of Hong Kong, Pokfulam Road, Hong Kong, China.

N-G. Carlsson. Department of Food Science, Chalmers

University of Technology, SE-412 96 Gothenburg, Sweden.

${ }^{1}$ Corresponding author (e-mail: ralf.greiner@bfel.de). were previously characterized from several Gram-positive Bacillus strains (Kerovuo et al. 2000; Tye et al. 2002). The three-dimensional structure of the BPP from Bacillus amyloliquefaciens resembles a six-bladed propeller that is mainly composed of highly curved antiparallel $\beta$-sheets (Ha et al. 2000). Crucial amino acid residues that are involved in the conformation of two phosphate binding sites and six calcium binding sites are also revealed by the structure. Three of the calcium binding sites are highaffinity binding sites that are responsible for thermostability, and the other three are low-affinity binding sites that are responsible for catalytic activity (Ha et al. 2000).

Recently, a protein (PhyS) with two BPP domains was characterized from the Gram-negative bacterium Shewanella oneidensis (Cheng and Lim 2006). While the fivebladed N-terminal BPP domain showed no phytase activity, the C-terminal six-bladed BPP domain was shown to exhibit highly specific activity towards phytate. Although this catalytic domain shares only $34 \%-36 \%$ sequence identity with Bacillus phytases, PhyS also exhibits calciumdependent enzymatic activity at neutral to alkaline $\mathrm{pH}$. Genome sequence analysis of the NCBI database and the Sargasso sea environmental database (Venter et al. 2004) 
indicate that BPP-like sequences are widely distributed in the genomes of a number of bacteria (Cheng and Lim 2006). While these BPP-like sequences only share low protein sequence identity $(20 \%-40 \%)$ with that of PhyS and Bacillus phytases, most of the essential amino acids that are responsible for calcium and phosphate binding are conserved in these sequences (Ha et al. 2000).

One of the objectives of this study was to delineate the phytate-hydrolysis pathway of PhyS and to identify the intermediates as well as the end product. In addition, the phytate degradation pathway of PhyS was compared with that of Bacillus phytases. The phytate-hydrolysis pathways of Bacillus phytases have been experimentally determined by Kerovuo et al. (2000) and Greiner et al. (2002) (Fig. 1). However, discrepancies exist between the two pathways and the computer-generated structural model of BPPs reported by Shin et al. (2001). This could be due to the presence of at least one contaminating phosphatase in the previous enzyme preparations. In this study, a higher quality enzyme preparation was employed and the new data are consistent with the proposed phytate-binding site in the structural model (Shin et al. 2001).

\section{Materials and methods}

\section{Chemicals}

Aspergillus niger phytase was obtained from Novo Nordisk (Copenhagen, Denmark). Phytic acid dodecasodium salt was from Aldrich (Steinheim, Germany). Ultrasep ${ }^{\mathrm{TM}} \mathrm{ES}$ 100 RP18 was purchased from Bischoff (Leonberg, Germany) and the high-pressure ion-pair chromatography (HPIC) column Carbo-Pac ${ }^{\mathrm{TM}}$ PA-100 was from Dionex (Sunnyvale, California, USA). AG1 X-4, 100-200 mesh resin was obtained from Bio-Rad (Munich, Germany). The source of the myo-inositol phosphate standards were as indicated by Skoglund et al. (1998).

\section{Purification of the phytate-degrading enzymes}

Purification of the phytate-degrading enzymes of A. niger (Greiner et al. 2001), Escherichia coli (Greiner et al. 1993), S. oneidensis (Cheng and Lim 2006), and Klebsiella terrigena (Greiner et al. 1997) was performed as described previously.

The encoding genes of the phytases from the different $\mathrm{Ba}$ cillus strains were inserted between the NdeI and HindIII sites of pET-22b(+) (Novagen, San Diego, California, USA) and over-expressed in E. coli BL21 (DE3). To lyse bacteria, cells were frozen at $-80{ }^{\circ} \mathrm{C}$ for $10 \mathrm{~min}$ and thawed at room temperature for $20 \mathrm{~min}$; freezing and thawing were repeated twice. After the final thaw, bacteria were sonicated for two 1 min intervals. Cell debris was removed by centrifugation at $10000 \mathrm{~g}, 4{ }^{\circ} \mathrm{C}, 30 \mathrm{~min}$ and phytases were purified from the clear supernatant by affinity chromatography using NiNT agarose (Qiagen, Valencia, California).

All phytases were purified to apparent homogeneity according to denaturing and nondenaturing polyacrylamide gel electrophoresis (data not shown).

\section{Buffers}

The following buffers were used for incubating myoinositol phosphate esters with the phytases: $0.1 \mathrm{~mol} / \mathrm{L}$ so-
Fig. 1. Pathway of phytate dephosphorylation by Bacillus phytases as suggested by Kerovuo et al. (2000) and Greiner et al. (2002). No suggestion about the absolute configuration of the generated myoinositol pentakisphosphates was given by Kerovuo et al. (2000).

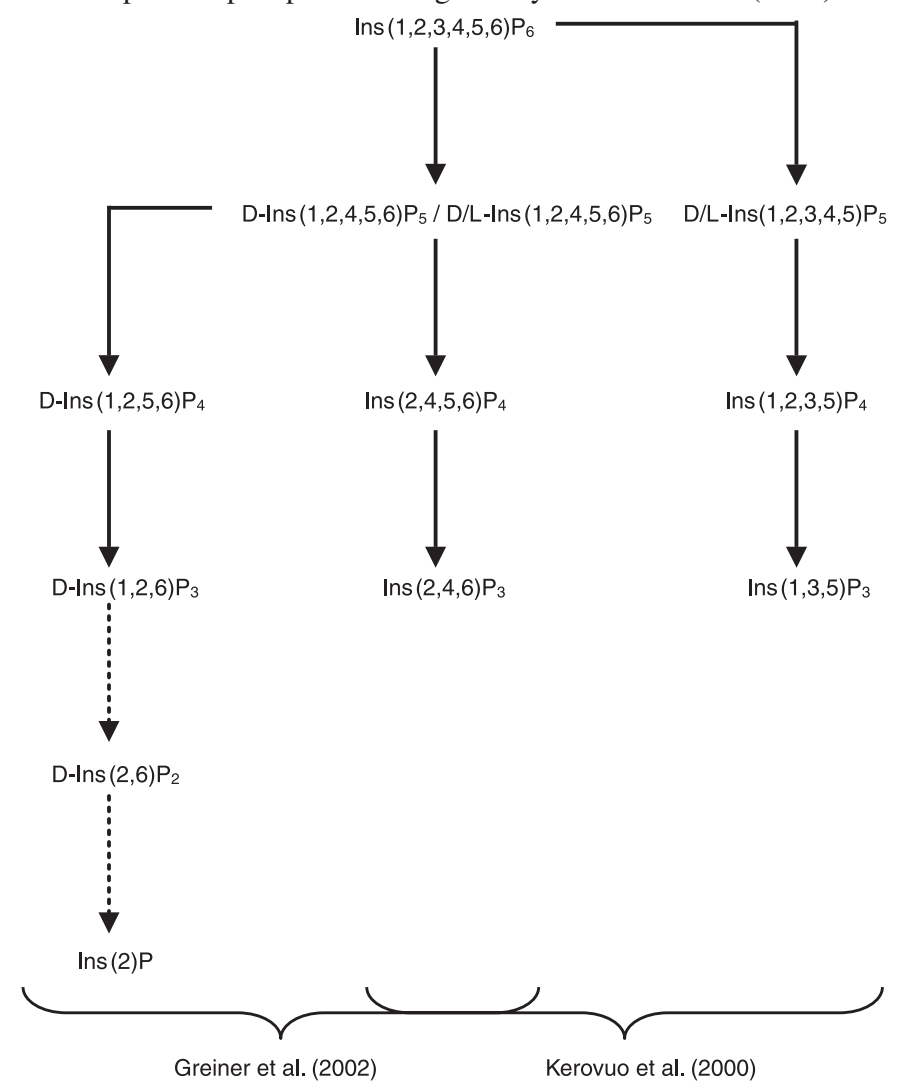

dium acetate, $\mathrm{pH} 4.5$ (E. coli), $0.1 \mathrm{~mol} / \mathrm{L}$ sodium acetate, $\mathrm{pH} 5.0$ (A. niger, $K$. terrigena), $0.1 \mathrm{~mol} / \mathrm{L}$ Tris- $\mathrm{HCl}$, $2 \mathrm{mmol} / \mathrm{L}$ calcium chloride, $\mathrm{pH} 7.5$ (B. subtilis 168, B. amyloliquefaciens ATCC 15841, B. amyloliquefaciens 45), $0.1 \mathrm{~mol} / \mathrm{L}$ Tris-maleate, and $4 \mathrm{mmol} / \mathrm{L}$ calcium chloride, pH 6.0 (S. oneidensis).

\section{Assay of phytase activity}

Phytase activity measurements were carried out at $37{ }^{\circ} \mathrm{C}$. The enzymatic reactions were started by the addition of $10 \mu \mathrm{L}$ of enzyme to the assay mixtures. The incubation mixture for phytase activity determination consisted of $350 \mu \mathrm{L}$ of incubation buffer containing $500 \mathrm{nmol}$ of sodium phytate. After an incubation time of $30 \mathrm{~min}$, the liberated inorganic phosphate was measured by a modification of the ammonium molybdate method (Heinonen and Lahti 1981).

\section{Heat treatment of Bacillus phytase preparations}

The Bacillus phytase preparations obtained after purification were incubated at $80{ }^{\circ} \mathrm{C}$ and $100{ }^{\circ} \mathrm{C}$ in the presence and absence of $5 \mathrm{mmol} / \mathrm{L}$ calcium for $10 \mathrm{~min}$, cooled to $4{ }^{\circ} \mathrm{C}$, and assayed using the standard phytase assay. To determine their residual activities toward the other phosphorylated compounds, phytate was substituted by $\mathrm{D}-\operatorname{Ins}(1,2,4,5,6) \mathrm{P}_{5}$, pyrophosphate, and ATP, respectively. 
Fig. 2. High-pressure ion-pair chromatography analysis of the enzymatically formed hydrolysis products of myo-inositol hexakisphosphate by the purified phytases from Shewanella oneidensis (A) and Bacillus amyloliquefaciens ATCC 15841 (B). First profile in each panel corresponds to a reference sample containing a mixture of myo-inositol phosphate standards. Peaks were identified as indicated in Skoglund et al. (1998). Peaks: A, Ins(1,3,4,5,6) $\mathrm{P}_{5} ; \mathrm{B}, \mathrm{D} / \mathrm{L}-\mathrm{Ins}(1,2,3,4,5) \mathrm{P}_{5} ; \mathrm{C}, \operatorname{Ins}(1,2,3,4,6) \mathrm{P}_{5} ; \mathrm{D}, \mathrm{D} / \mathrm{L}-\mathrm{Ins}(1,4,5,6) \mathrm{P}_{4} ; \mathrm{F}, \mathrm{D} / \mathrm{L}-\mathrm{Ins}(1,2,5,6) \mathrm{P}_{4} ; \mathrm{G}, \mathrm{D} / \mathrm{L}-$

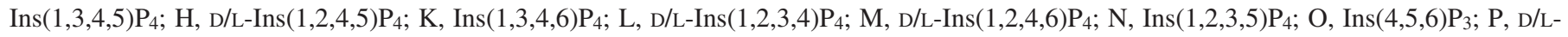
$\operatorname{Ins}(1,5,6) \mathrm{P}_{3} ; \mathrm{R}, \mathrm{D} / \mathrm{L}-\operatorname{Ins}(1,4,5) \mathrm{P}_{3} ; \mathrm{S}, \mathrm{D} / \mathrm{L}-\operatorname{Ins}(1,2,6) \mathrm{P}_{3}$, Ins(1,2,3) $\mathrm{P}_{3} ; \mathrm{T}, \mathrm{D} / \mathrm{L}-\operatorname{Ins}(1,3,4) \mathrm{P}_{3} ; \mathrm{U}, \mathrm{D} / \mathrm{L}-\operatorname{Ins}(2,4) \mathrm{P}_{2} ; \mathrm{X}, \mathrm{D} / \mathrm{L}-\operatorname{Ins}(1,2) \mathrm{P}_{2}, \operatorname{Ins}(2,5) \mathrm{P}_{2}$, D/LIns(4,5) $\mathrm{P}_{2}$; and $\mathrm{Y}, \mathrm{D} / \mathrm{L}-\mathrm{Ins}(1,4) \mathrm{P}_{2}$, D/L-Ins( $(1,6) \mathrm{P}_{2}$.

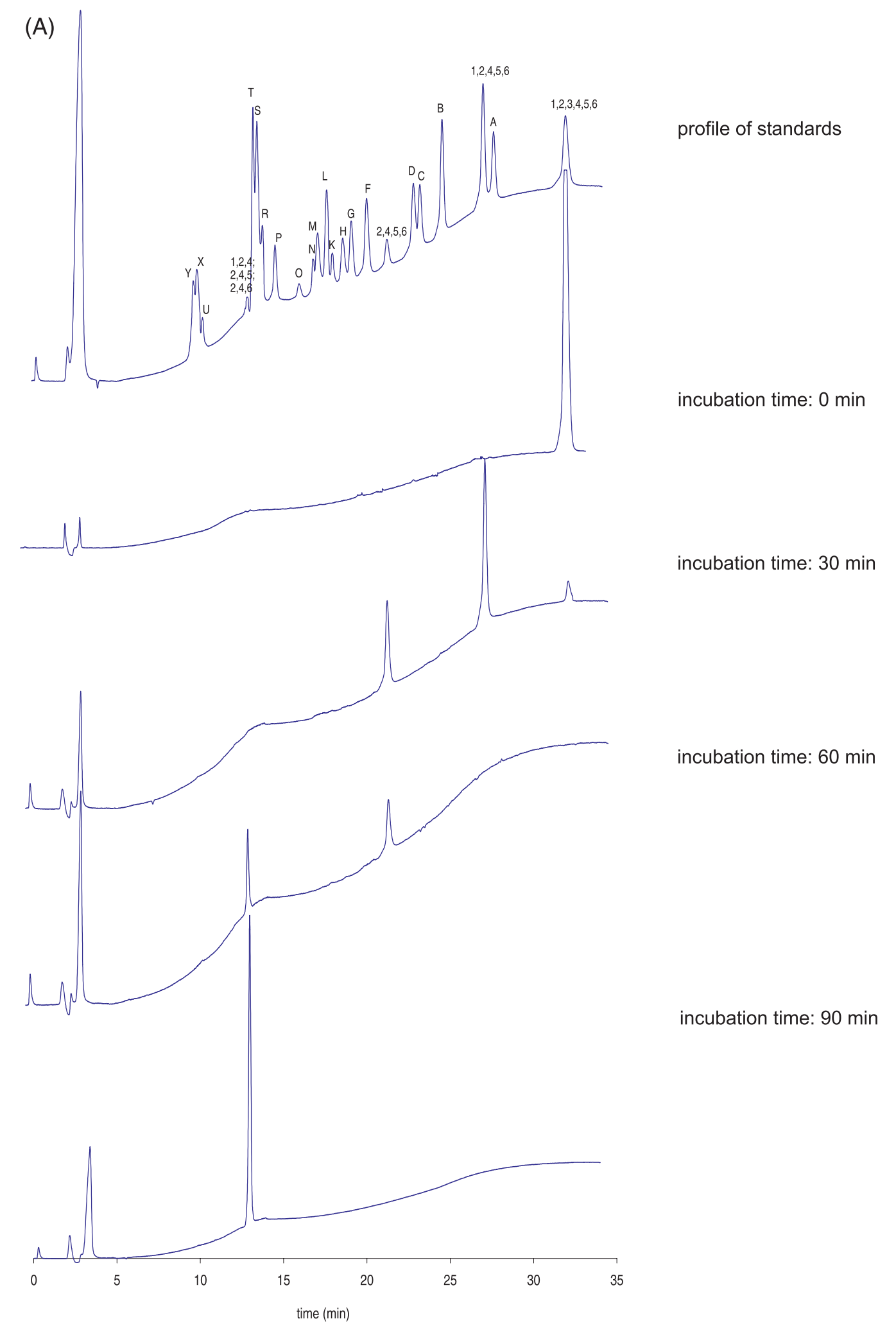


Fig. 2 (continued).

(B)
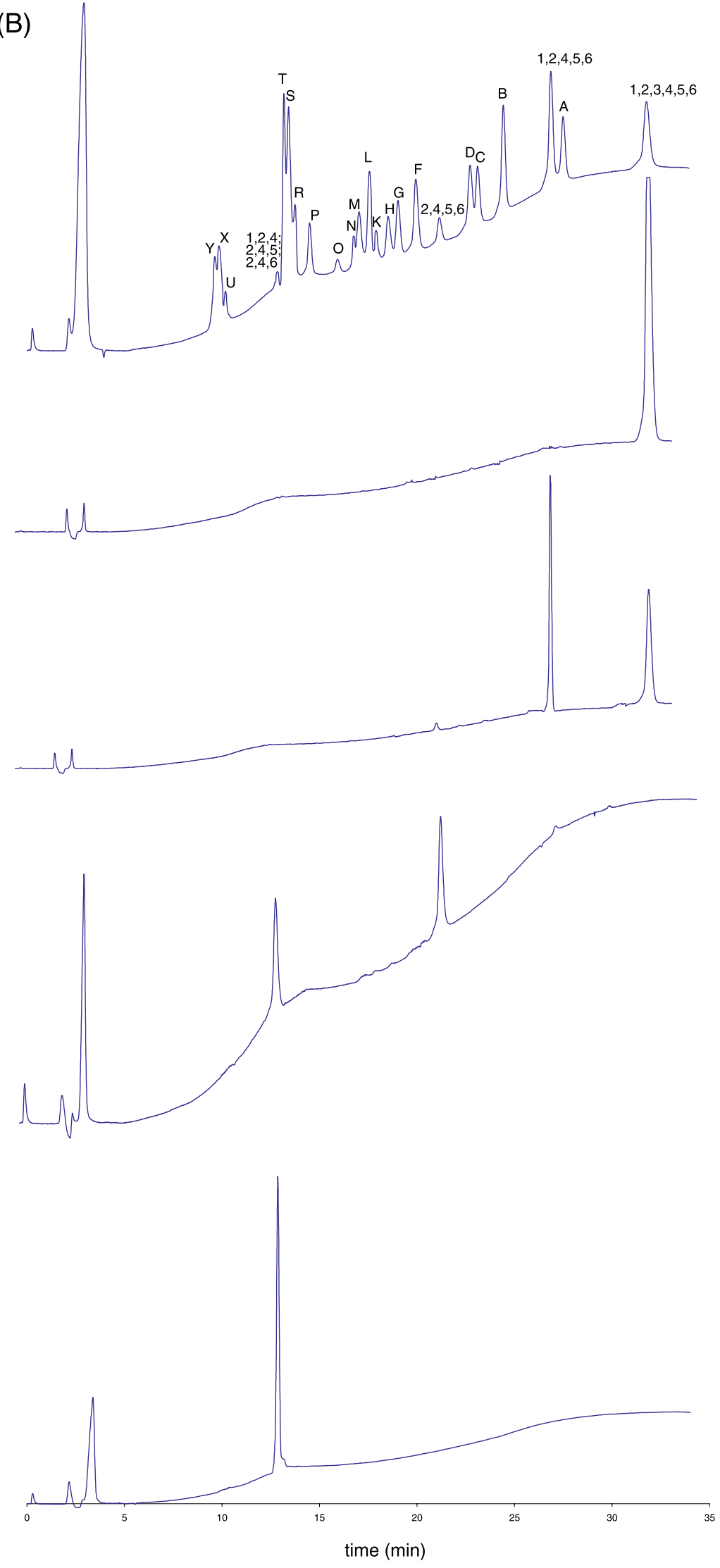

profile of standards

incubation time: 0 min

incubation time: $30 \mathrm{~min}$

incubation time: $60 \mathrm{~min}$

incubation time: 90 min 
Preparation of myo-inositol pentakis- and tris-phosphate isomers

myo-Inositol hexakisphosphate $(50 \mu \mathrm{mol})$ in the corresponding incubation buffer were incubated at $37{ }^{\circ} \mathrm{C}$ with 0.4 $\mathrm{U}$ of the phytases in a final volume of $20 \mathrm{~mL}$. After an incubation period of 60 min (myo-inositol pentakisphosphate preparation) or $8 \mathrm{~h}$ (myo-inositol trisphosphate preparation), the reactions were stopped by heat treatment $\left(95{ }^{\circ} \mathrm{C}, 10 \mathrm{~min}\right)$. The incubation mixtures were lyophilized and the dry residues were dissolved in $10 \mathrm{~mL}$ of $0.2 \mathrm{~mol} / \mathrm{L}$ ammonium formate, $\mathrm{pH}$ 2.5. The solutions were loaded onto a Q-Sepharose column $(2.6 \mathrm{~cm} \times 90 \mathrm{~cm})$ equilibrated with $0.2 \mathrm{~mol} / \mathrm{L}$ ammonium

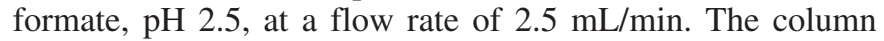
was washed with $500 \mathrm{~mL}$ of $0.2 \mathrm{~mol} / \mathrm{L}$ ammonium formate, $\mathrm{pH} 2.5$; the bound myo-inositol trisphosphates were eluted with a linear gradient from 0.2 to $0.6 \mathrm{~mol} / \mathrm{L}$ ammonium formate, $\mathrm{pH} 2.5(1 \mathrm{~L})$ and the bound myo-inositol pentakisphosphates with a linear gradient from 1.0 to $1.4 \mathrm{~mol} / \mathrm{L}$ ammonium formate, $\mathrm{pH} 2.5(1000 \mathrm{~mL})$ at $2.5 \mathrm{~mL} / \mathrm{min}$. Fractions of $10 \mathrm{~mL}$ were collected. From even-numbered tubes, $100 \mu \mathrm{L}$ aliquots were lyophilized. The residues were dissolved in $1.5 \mathrm{mmol} / \mathrm{L}$ sulfuric acid and incubated for $90 \mathrm{~min}$ at $165^{\circ} \mathrm{C}$ to hydrolyze the eluted myo-inositol phosphates completely. The liberated phosphate was quantified by a modification of the ammonium molybdate method (Heinonen and Lahti 1981). The content of the fraction tubes corresponding to the myo-inositol tris- and pentakis-phosphates, respectively, were pooled and lyophilized until only a dry residue remained. Ten millilitres of water was used to redissolve the residues. Lyophilization and redissolving were repeated twice to completely remove ammonium formate. myo-Inositol phosphate concentrations were determined by high-pressure liquid chromatography (HPLC) HPIC on Ultrasep ${ }^{\mathrm{TM}}$ ES 100 RP18 (2 mm $\times$ $250 \mathrm{~mm}$ ). The column was run at $45^{\circ} \mathrm{C}$ and $0.2 \mathrm{~mL} / \mathrm{min}$ of an eluant consisting of formic acid-methanol-water-TBAH (tetrabutylammonium hydroxide) (44:56:5:1.5 by volume), $\mathrm{pH} 4.25$, as described by Sandberg and Ahderinne (1986). A mixture of the individual myo-inositol phosphate esters $\left(\mathrm{IP}_{3}-\right.$ $\mathrm{IP}_{6}$ ) was used as a standard. The purity of the myo-inositol phosphate preparations was determined on a HPIC system as described by Skoglund et al. (1998).

Production of enzymatically formed hydrolysis products

The enzymatic reaction was started at $37{ }^{\circ} \mathrm{C}$ by addition of $50 \mu \mathrm{L}$ of the suitably diluted solution of the phytases from $S$. oneidensis or from different Bacillus spp. to the incubation mixtures $(100 \mathrm{mU} / \mathrm{mL})$. The incubation mixture consisted of either $1250 \mu \mathrm{L}$ of $0.1 \mathrm{~mol} / \mathrm{L}$ Tris-maleate, $\mathrm{pH} 6.0$ containing $5 \mu \mathrm{mol} \mathrm{CaCl}_{2}$ and $1.25 \mathrm{mmol}$ sodium phytate (S. oneidensis) or $1250 \mu \mathrm{L}$ of $0.1 \mathrm{~mol} / \mathrm{L}$ Tris- $\mathrm{HCl}$, $\mathrm{pH} 7.5$ containing $2.5 \mu \mathrm{mol} \mathrm{CaCl}_{2}$ and $2.5 \mu \mathrm{mol}$ sodium phytate (Bacillus sp.). From the incubation mixture, $150 \mu \mathrm{L}$ samples were removed periodically and the reaction was stopped by heat treatment $\left(90{ }^{\circ} \mathrm{C}, 5 \mathrm{~min}\right)$. For the identification of phytate degradation products, $50 \mu \mathrm{L}$ of the heattreated samples were chromatographed on a HPIC system as described by Skoglund et al. (1998).

\section{Identification of enzymatically formed hydrolysis products}

Isomers of myo-inositol phosphate were determined and separated on a HPIC system using a Carbo Pac PA-100 $(4 \mathrm{~mm} \times 250 \mathrm{~mm})$ analytical column and a gradient of $5 \%-$ $98 \% \mathrm{HCl}(0.5 \mathrm{~mol} / \mathrm{L}, 0.8 \mathrm{~mL} / \mathrm{min})$ as described by Skoglund et al. (1998). The eluants were mixed in a post-column reactor with $0.1 \%\left(\mathrm{Fe}\left(\mathrm{NO}_{3}\right)_{3} \cdot 9 \mathrm{H}_{2} \mathrm{O}\right.$ in a $2 \%(v / v) \mathrm{HClO}_{4}$ solution (0.4 $\mathrm{mL} / \mathrm{min})$, according to Phillippy and Bland (1988). The combined flow rate was $1.2 \mathrm{~mL} / \mathrm{min}$.

\section{Kinetic studies with the pure myo-inositol phosphate isomers}

In addition to phytate, the following myo-inositol phosphate isomers were used as substrates for $K_{\mathrm{m}}$ and $k_{\text {cat }}$ determination: D-Ins $(1,2,4,5,6) \mathrm{P}_{5}$ (product of $A$. niger phytase), the myo-inositol pentakisphosphates and myo-inositol trisphosphates produced by the phytases from $S$. oneidensis, B. subtilis 168, B. amyloliquefaciens ATCC 15841, and B. amyloliquefaciens 45 . The incubation mixture consisted of $350 \mu \mathrm{L}$ incubation buffer containing the phosphorylated compound in a serial dilution of a concentrated stock solution $(2.0 \mathrm{mmol} / \mathrm{L})$. The enzymatic reactions were started by adding $10 \mathrm{mU}$ of the phytases to the assay mixtures. After an incubation period of $30 \mathrm{~min}$, the liberated phosphate was quantified by a modification of the ammonium molybdate method (Heinonen and Lahti 1981). The rate of reaction was linear for the 30 min incubation time (data not shown). Activity (U) was expressed as $\mu$ mol phosphate liberated per min. Blanks were run by the addition of ammonium molybdate solution prior to the addition of enzyme solution to the assay mixtures. The kinetic constants $\left(K_{\mathrm{m}}, v_{\max }\right)$ were calculated from the Lineweaver-Burk plots of the data. For the calculation of $k_{\text {cat }}$, the following molecular masses were used: $40 \mathrm{kDa}$ for the Bacillus phytases (Greiner et al. 2002) and $73 \mathrm{kDa}$ for the S. oneidensis phytase (Cheng and Lim 2006).

\section{Quantification of liberated phosphate}

The liberated phosphate was quantified by a modification of the ammonium molybdate method (Heinonen and Lahti 1981). A $1.5 \mathrm{~mL}$ volume of a freshly prepared solution of acetone-5 mol/L sulfuric acid-10 $\mathrm{mmol} / \mathrm{L}$ ammonium molybdate $(2: 1: 1$ by volume) and, thereafter, $100 \mu \mathrm{L}$ of $1.0 \mathrm{~mol} / \mathrm{L}$ citric acid were added to $400 \mu \mathrm{L}$ of the suitably diluted hydrolysis mixtures or to the mixtures of the phytase assay. Any cloudiness was removed by centrifugation prior to the measurement of absorbance at $355 \mathrm{~nm}$. To quantify the released phosphate a calibration curve was produced over 5-600 nmol phosphate.

\section{Statistical methods}

The Student's $t$ test was used for statistical comparison.

\section{Results}

\section{Intermediates of enzymatic myo-inositol hexakisphosphate dephosphorylation}

Identification of the hydrolysis products of myo-inositol hexakisphosphate generated by PhyS was performed by HPIC analysis. The chromatographic profile of the zerotime control indicated only the myo-inositol hexakisphosphate peak (Fig. 2A). After $30 \mathrm{~min}$ of incubation, the quantity of myo-inositol hexakisphosphate had decreased 
Table 1. Kinetic constants for the enzymatic dephosphorylation of myo-inositol pentakisphosphate $\left(\mathrm{IP}_{5}\right)$.

\begin{tabular}{lcc}
\hline & $\begin{array}{l}\mathrm{IP}_{5} \text { generated by } \\
\text { the A. niger } \\
\text { phytase }\end{array}$ & $\begin{array}{l}\mathrm{IP}_{5} \text { generated by } \\
\text { the BPP under } \\
\text { investigation }\end{array}$ \\
\hline $\begin{array}{l}\text { Shewanella oneidensis } \\
K_{\mathrm{m}}(\mu \mathrm{mol} / \mathrm{L})\end{array}$ & $102 \pm 4$ \\
$k_{\mathrm{cat}}(/ \mathrm{s})$ & $156 \pm 3$ & $107 \pm 8$ \\
Bacillus amyloliquefaciens & ATCC & 15841 \\
$K_{\mathrm{m}}(\mu \mathrm{mol} / \mathrm{L})$ & $505 \pm 17$ & $508 \pm 22$ \\
$k_{\mathrm{cat}}(/ \mathrm{s})$ & $17.2 \pm 0.5$ & $16.9 \pm 0.3$ \\
Aspergillus niger & \\
$K_{\mathrm{m}}(\mu \mathrm{mol} / \mathrm{L})$ & $132 \pm 10$ & $142 \pm 19$ \\
$k_{\mathrm{cat}}(/ \mathrm{s})$ & $155 \pm 11$ & $159 \pm 13$ \\
\hline
\end{tabular}

Note: The data are means \pm SD of five independent experiments. Values were not found to be significantly different $(P<$ $0.05)$. BPP, $\beta$-propeller phytase.

and D/L-Ins $(1,2,4,5,6) \mathrm{P}_{5}$ appeared as the major degradation product, accompanied by some amounts of $\operatorname{Ins}(2,4,5,6) \mathrm{P}_{4}$. After $60 \mathrm{~min}$ of incubation, myo-inositol hexakisphosphate and the myo-inositol pentakisphosphate were completely degraded to $\operatorname{Ins}(2,4,5,6) \mathrm{P}_{4}$ and a myo-inositol trisphosphate which co-eluted with $\operatorname{Ins}(2,4,6) \mathrm{P}_{3}, \mathrm{D} / \mathrm{L}-\operatorname{Ins}(2,4,5) \mathrm{P}_{3}$, and $\mathrm{D} / \mathrm{L}-\mathrm{Ins}(1,2,4) \mathrm{P}_{3}$. After $90 \mathrm{~min}$ of incubation only the myo-inositol trisphosphate peak remained. Prolonged incubation times and increasing enzyme concentration did not result in any appearance of myo-inositol phosphates with less than three phosphate residues.

\section{Identification of the absolute configuration of the generated myo-inositol pentakisphosphate isomer}

To determine the absolute configuration of the myo-inositol pentakisphosphate isomer generated by PhyS, kinetic studies with the purified myo-inositol pentakisphosphate isomers generated either by the A. niger enzyme or the phytase from $S$. oneidensis were performed. The enzymes were added to sequentially diluted solutions of the purified myo-inositol pentakisphosphate isomers and the kinetic parameters $\left(K_{\mathrm{m}}, v_{\max }\right)$ were calculated from the LineweaverBurk plots of the data (Table 1). For each individual enzyme, the $K_{\mathrm{m}}$, and $k_{\text {cat }}$ for the myo-inositol pentakisphosphate dephosphorylation reactions were almost identical, irrespective of the source of the myo-inositol pentakisphosphate isomers. Thus, these myo-inositol pentakisphosphates are identical. Since it is known that the A. niger phytase predominantly generates the $\mathrm{D}-\operatorname{Ins}(1,2,4,5,6) \mathrm{P}_{5}$ isomer (Ullah and Phillippy 1988), D-Ins(1,2,4,5,6) $\mathrm{P}_{5}$ is the first degradation product of myo-inositol hexakisphosphate dephosphorylation by the phytase from $S$. oneidensis.

\section{Identity of the myo-inositol trisphosphate isomer product}

A clear identification of the myo-inositol trisphosphate isomer could not be obtained by HPIC since not all theoretically existing isomers were available. The sole myo-inositol tetrakisphosphate intermediate formed by PhyS $\left(\operatorname{Ins}(2,4,5,6) \mathrm{P}_{4}\right)$ may be degraded to $\mathrm{D} / \mathrm{L}-\operatorname{Ins}(2,4,5) \mathrm{P}_{3}, \operatorname{Ins}(2,4,6) \mathrm{P}_{3}$, and Ins $(4,5,6) \mathrm{P}_{3}$. According to $\mathrm{HPIC}$, Ins $(4,5,6) \mathrm{P}_{3}$ had to be excluded as an intermediate, since this myo-inositol phosphate eluted well resolved from the $\mathrm{IP}_{3}$ peak generated by PhyS (Fig. 2A). To get more information on the myo-inositol trisphosphate produced by PhyS, the myo-inositol trisphosphate was purified and incubated with the phytases of $E$. coli and $K$. terrigena. Both enzymes showed no activity towards the myo-inositol trisphosphate generated by PhyS. The data obtained are consistent with the assumption that $\operatorname{Ins}(2,4,6) \mathrm{P}_{3}$ is the end product of phytate dephosphorylation by PhyS. Escherichia coli phytase is capable of dephosphorylating D$\operatorname{Ins}(2,4,5) \mathrm{P}_{3}$ (Greiner et al. 2000) and that $\operatorname{Ins}(2,4,6) \mathrm{P}_{3}$ is not a substrate of the $K$. terrigena phytase (Greiner and Carlsson 2006). Thus, the BPP from $S$. oneidensis prefers, in contrast to the histidine acid phytases, the hydrolysis of every second phosphate over that of adjacent ones.

\section{Pathway of phytate degradation by Bacillus phytases}

The presence of at least one additional phosphatase in the phytase preparation used for the elucidation of the enzymatic phytate degradation pathway might be one reason for the observed discrepancy between the previous model of phytate degradation by Bacillus phytases established by Greiner et al. (2002) (Fig. 1) and the structural computer model of phytate binding (Shin et al. 2001). Since it was shown previously that the phytase preparation used for pathway elucidation were apparently homogeneous according to denaturing and nondenaturing polyacrylamide gel electrophoresis, heat treatment was used to determine whether one or several enzymes were responsible for the hydrolysis of phytate and partially phosphorylated myo-inositol phosphates. The Bacillus phytases purified in this study were partially inactivated by heat treatment and the residual activities toward phytate, ATP, pyrophosphate, and DIns $(1,2,4,5,6) \mathrm{P}_{5}$ were measured to determine if the activities were separable. Heat treatment resulted in no significant difference in loss of activity toward the four phosphorylated compounds studied (Table 2), thus establishing the homogeneity of the enzyme preparations. However, the enzyme preparations used in the previous work (Greiner et al. 2002) were clearly shown to lose significantly higher activity toward phytate compared to ATP, pyrophosphate, and DIns $(1,2,4,5,6) \mathrm{P}_{5}$ (Table 2). In addition, the enzyme preparation used in the previous work was capable of hydrolyzing ATP, whereas the enzyme preparation used in this study did not accept ATP as a substrate. Thus, it can be concluded that these phytase preparations contained at least one additional phosphatase as an impurity.

The highly purified Bacillus phytase preparations were used for phytate degradation studies. The chromatographic profiles obtained during phytate dephosphorylation were indistinguishable for all of these phytases. Therefore, phytate degradation by the phytase from $B$. amyloliquefaciuens ATCC 15841 is shown as an example in Fig. 2B. Combination of HPLC analysis and kinetic studies (Table 1) identified the partially phosphorylated $m y o$-inositol phosphate products as $\mathrm{D}-\operatorname{Ins}(1,2,4,5,6) \mathrm{P}_{5}$, $\operatorname{Ins}(2,4,5,6) \mathrm{P}_{4}$, and $\operatorname{Ins}(2,4,6,) \mathrm{P}_{3}$. No other phytate dephosphorylation products could be identified even after prolonged incubation times in the presence of high enzyme concentrations. 
Table 2. Residual activity toward various phosphorylated compounds after heat treatment.

\begin{tabular}{lllll}
\hline \multicolumn{5}{c}{ Residual activity in U/mL $(\%)$ toward: } \\
\cline { 2 - 5 } Treatment & Phytate & D-Ins $(1,2,4,5,6) \mathrm{P}_{5}$ & Pyrophosphate & ATP \\
\hline Bacillus amyloliquefaciens ATCC 15841 phytase preparation used in this study & \\
Control & $126.4 \pm 10.3(100)$ & $97.7 \pm 6.8(100)$ & $6.2 \pm 0.4(100)$ & 0 \\
10 min at $80{ }^{\circ} \mathrm{C}$ with $\mathrm{Ca}^{2+}$ & $63.6 \pm 4.7(50.3)$ & $49.5 \pm 3.9(50.7)$ & $3.0 \pm 0.2(48.4)$ & nd \\
10 min at $80{ }^{\circ} \mathrm{C}$ without Ca ${ }^{2+}$ & $0(0)$ & $0(0)$ & $0(0)$ & nd \\
10 min at $100{ }^{\circ} \mathrm{C}$ with $\mathrm{Ca}^{2+}$ & $23.1 \pm 1.8(18.3)$ & $17.6 \pm 1.3(18.0)$ & $1.2 \pm 0.1(19.4)$ & nd \\
Bacillus amyloliquefaciens ATCC $\mathbf{1 5 8 4 1}$ phytase preparation used in Greiner et al. (2002) & \\
Control & $139.1 \pm 10.7(100)$ & $13.9 \pm 14.3(100)$ & $14.0 \pm 1.1(100)$ & $190.8 \pm 12.8(100)$ \\
10 min at $80{ }^{\circ} \mathrm{C}$ with $\mathrm{Ca}^{2+}$ & $74.0 \pm 5.2(53.2)$ & $141.5 \pm 9.7(66.1)$ & $9.5 \pm 0.8(67.9)$ & $148.7 \pm 9.3(77.9)$ \\
10 min at $80{ }^{\circ} \mathrm{C}$ without $\mathrm{Ca}^{2+}$ & $0(0)$ & $80.8 \pm 5.2(37.8)$ & $5.4 \pm 0.4(38.6)$ & $143.8 \pm 8.7(75.4)$ \\
10 min at $100{ }^{\circ} \mathrm{C}$ with $\mathrm{Ca}^{2+}$ & $25.9 \pm 1.9(18.6)$ & $51.7 \pm 3.2(24.2)$ & $3.5 \pm 0.2(25.0)$ & $53.7 \pm 4.1(28.1)$ \\
\hline
\end{tabular}

Note: The data are means \pm SD of five independent experiments. nd, not determined.

\section{Discussion}

Two phosphate binding sites have been identified in the active site of Bacillus phytases (Shin et al. 2001); the "cleavage site," where hydrolysis of the phytate phosphate takes place, and the "affinity site," which increases the binding affinity for substrates containing adjacent phosphate groups. The existence of two nonequivalent phosphate binding sites points to a preferred hydrolysis of every second phosphate over that of adjacent ones and the generation of a myo-inositol trisphosphate as the final product of phytate degradation. Superposition of phytate into the active site suggested that only the phosphate groups at position C-3 and C- 6 are accessible for cleavage by the Bacillus phytases and phytate degradation should proceed either via $\operatorname{Ins}(2,4,5,6) \mathrm{P}_{4}$ to $\operatorname{Ins}(2,4,6) \mathrm{P}_{3}$ or via $\operatorname{Ins}(1,2,3,5) \mathrm{P}_{4}$ to Ins $(1,3,5) \mathrm{P}_{3}$ (Shin et al. 2001). However, phytate degradation studies only identified D-Ins $(1,2,4,5,6) \mathrm{P}_{5}$ (Greiner et al. 2002 ) or $\mathrm{D} / \mathrm{L}-\mathrm{Ins}(1,2,4,5,6) \mathrm{P}_{5}$ (Kerovuo et al. 2000) as the first intermediate (Fig. 1). Both studies suggested a dual pathway of enzymatic phytate hydrolysis. The pathway given by Kerovuo et al. (2000) fits with the structural computer model, but $\mathrm{D}-\mathrm{Ins}(1,2,3,4,5) \mathrm{P}_{5}$ did not accumulate during phytate hydrolysis and $\operatorname{Ins}(1,2,3,5) \mathrm{P}_{4}$ was only found in small amount. The degradation pathway given by Greiner et al. (2002) fits only partly with the structural computer model since removal of the phosphate residue at C-4 of DIns $(1,2,4,5,6) \mathrm{P}_{5}$ is not consistent with the preferred hydrolysis of every second phosphate group. Heat treatment studies showed that there was extra phosphatase activity in the enzyme preparation previously used by Greiner et al. (2002). In this study a higher quality enzyme preparation was used for phytate degradation pathway elucidation.

Despite low protein sequence identity and different origins, e.g., from Gram-negative (S. oneidensis) or from Gram-positive (Bacillus sp.) bacteria, all BPPs under investigation shared a common phytate degradation pathway via $\mathrm{D}-\operatorname{Ins}(1,2,4,5,6) \mathrm{P}_{5}$ and $\operatorname{Ins}(2,4,5,6) \mathrm{P}_{4}$ to $\operatorname{Ins}(2,4,6,) \mathrm{P}_{3}$. Since all theoretically existing myo-inositol pentakis- and tetrakisphosphate isomers are well resolved on the HPIC system (Fig. 2), the identity of the myo-inositol pentakis- and tetrakis-phosphate isomers was sufficiently established by this system. In contrast, the identity of the myo-inositol trisphosphates generated by the BPPs had to be confirmed by an indirect method, which was a comparison of the sensitivity of their products towards another class of phytase.

In summary, no dual phytate degradation pathway could be established for the BPPs as reported previously by Kerovuo et al. (2000) and Greiner et al. (2002). The following four reasons point to the correctness of the phytate degradation pathway given here. First, all three studies on phytate dephosphorylation by BPPs reveal $\operatorname{Ins}(2,4,6) \mathrm{P}_{3}$ as a final dephosphorylation product. Second, heat treatment studies point to the absence of additional phosphatase activity in the Bacillus phytase preparations. Third, in this study as well as in our previous one (Greiner et al. 2002), Ins $(1,3,5) \mathrm{P}_{3}$ is not detected as a final degradation product of the BPPs as reported by Kerovuo et al. (2000). The formation of $\operatorname{Ins}(1,3,5) \mathrm{P}_{3}$ upon action on phytate would require hydrolysis of the phosphate residue at position C-2 of the myo-inositol ring. This phosphate residue was shown to be resistant to dephosphorylation by phytases (Konietzny and Greiner 2002). Furthermore, phytases have been shown to remove phosphate stepwise from the phytate molecule, whereby each myo-inositol intermediate is released from the enzyme and may become a substrate for further hydrolysis (Konietzny and Greiner 2002). However, Kerovuo et al. (2000) were unable to identify D/L-Ins $(1,2,4,5,6) \mathrm{P}_{5}$ as an intermediate of phytate dephosphorylation by a Bacillus phytase. In addition, Ins $(1,2,3,5) \mathrm{P}_{4}$ did not accumulate to the same extent as Ins $(2,4,5,6) \mathrm{P}_{4}$ (Kerovuo et al. 2000). The reason for the appearance of an additional myo-inositol trisphosphate in the study of Kerovuo et al. (2000) is still unclear. Finally, the phytate degradation pathway is consistent with the structural data and results of a substrate recognition model (Shin et al. 2001).

\section{References}

Cheng, C., and Lim, B.L. 2006. $\beta$-Propeller phytases in the aquatic environment. Arch. Microbiol. 185: 1-13. doi:10.1007/s00203005-0080-6. PMID:16402222.

Greiner, R., and Carlsson, N.-G. 2006. myo-Inositol phosphate isomers generated by the action of a phytate-degrading enzyme from Klebsiella terrigena upon phytate. Can. J. Microbiol. 52: 759-768. doi:10.1139/W06-028. PMID:16917535.

Greiner, R., Konietzny, U., and Jany, K.-D. 1993. Purification and characterization of two phytases from Escherichia coli. Arch. 
Biochem. Biophys. 303: 107-113. doi:10.1006/abbi.1993.1261. PMID:8387749.

Greiner, R., Haller, E., Konietzny, U., and Jany, K.-D. 1997. Purification and characterization of a phytase from Klebsiella terrigena. Arch. Biochem. Biophys. 341: 201-206. doi:10.1006/abbi. 1997.9942. PMID:9169005.

Greiner, R., Carlsson, N., and Alminger, M.L. 2000. Stereospecificity of myo-inositol hexakisphosphate dephosphorylation by a phytate-degrading enzyme of Escherichia coli. J. Biotechnol. 84: 53-62. PMID:11035187.

Greiner, R., Larsson Alminger, M., and Carlsson, N.-G. 2001. Stereospecificity of myo-inositol hexakisphosphate dephosphorylation by a phytate-degrading enzyme of baker's yeast. J. Agric. Food Chem. 49: 2228-2233. doi:10.1021/jf0100090. PMID: 11368581.

Greiner, R., Farouk, A., Larsson Alminger, M., and Carlsson, N.-G. 2002. The pathway of dephosphorylation of myo-inositol hexakisphosphate by phytate-degrading enzymes of different $\mathrm{Ba}$ cillus spp. Can. J. Microbiol. 48: 986-994. doi:10.1139/w02097. PMID:12556126.

Ha, N.C., Oh, B.C., Shin, S., Kim, H.J., Oh, T.K., Kim, Y.O., et al. 2000. Crystal structures of a novel, thermostable phytase in partially and fully calcium-loaded states. Nat. Struct. Biol. 7: 147153. PMID:10655618.

Heinonen, J.K., and Lahti, R.J. 1981. A new and convenient colorimetric determination of inorganic orthophosphate and its application to the assay of inorganic pyrophosphatase. Anal. Biochem. 113: 313-317. doi:10.1016/0003-2697(81)90082-8. PMID:6116463.

Kerovuo, J., Rouvinen, J., and Hatzack, F. 2000. Hydrolysis of phytic acid by Bacillus phytase. Biochem. J. 352: 623-628. doi:10.1042/0264-6021:3520623. PMID:11104666.
Konietzny, U., and Greiner, R. 2002. Molecular and catalytic properties of phytases. Int. J. Food Sci. Technol. 37: 791-812.

Mullaney, E.J., and Ullah, A.H. 2005. Phytases: attributes, catalytic mechanisms and applications. In Proceedings of the Bouyoucos Conference: Inositol Phosphates in the Soil-Plant-Animal System, Sun Valley, Idaho, USA, 21-24 August 2005. Edited by B.L. Turner, A.E. Richardson, and E.J. Mullaney. pp. 17-18.

Phillippy, B.Q., and Bland, J.M. 1988. Gradient ion chromatography of inositol phosphates. Anal. Biochem. 175: 162-166. doi:10.1016/0003-2697(88)90374-0. PMID:3245565.

Sandberg, A.-S., and Ahderinne, R. 1986. HPLC method for determination of inositol tri-, tetra-, penta-, and hexaphosphate in foods and intestinal contents. J. Food Sci. 51: 547-550. doi:10. 1111/j.1365-2621.1986.tb13875.x.

Shin, S., Ha, N.C., Oh, B.C., Oh, T.K., and Oh, B.H. 2001. Enzyme mechanism and catalytic property of $\beta$ propeller phytase. Structure, $\mathbf{9}$ : 851-858. doi:10.1016/S0969-2126(01)00637-2. PMID:11566134.

Skoglund, E., Carlsson, N.-G., and Sandberg, A.-S. 1998. High-performance chromatographic separation of inositol phosphate isomers on strong anion exchange columns. J. Agric. Food Chem. 46: 1877-1882. doi:10.1021/jf9709257.

Tye, A.J., Siu, F.K.Y., Leung, T.Y.C., and Lim, B.L. 2002. Molecular cloning and the biochemical characterization of two novel phytases from B. subtilis 168 and B. licheniformis. Appl. Microbiol. Biotechnol. 59: 190-197. PMID:12111145.

Ullah, A.H.J., and Phillippy, B.Q. 1988. Imobilization of Aspergillus ficuum phytase: product characterization of the bioreactor. Prep. Biochem. 18: 483-489. PMID:2852808.

Venter, J.C., Remington, K., Heidelberg, J.F., Halpern, A.L., Rusch, D., Eisen, J.A., et al. 2004. Environmental genome shotgun sequencing of the Sargasso Sea. Science (Washington, D.C.), 304: 66-74. doi:10.1126/science.1093857. PMID:15001713. 
Copyright of Canadian Journal of Microbiology is the property of NRC Research Press and its content may not be copied or emailed to multiple sites or posted to a listserv without the copyright holder's express written permission. However, users may print, download, or email articles for individual use. 